\title{
Feasibility Study on Production of Geopolymer Masonry Bricks with Phosphogypsum and Fly Ash (Oven-Dried)
}

\author{
Jagmohan Vijay Jandhyala, ${ }^{1, *}$, Prof. H. Sudarsana Rao ${ }^{2}$, Prof. Vaishali. G. Ghorpade ${ }^{3}$ \\ $I^{*}$ Research-Scholar, Faculty of Civil Engineering, Jawaharlal Nehru Technological University, Anantapur, Andhra Pradesh, India. \\ ${ }^{2}$ Professor of Civil Engineering, Jawaharlal Nehru Technological University, Anantapur, Andhra Pradesh, India. \\ ${ }^{3}$ Professor of Civil Engineering, Jawaharlal Nehru Technological University, Anantapur, Andhra Pradesh, India.
}

*Corresponding Author

\begin{abstract}
Present annual fly ash production is in excess of 750 million tons worldwide, which is produced from various industries like pharmaceuticals, power plants, steel production, automobiles industries etc. These industries are necessary for the society and hence its production cannot be stopped. So, there seems to be no way in which fly ash production can be stopped since it is a by-product from these industries. The only other alternative would be in utilizing the fly ash produced in producing alternative construction materials. It would be even better if other such materials like fly ash are also utilized either in combination with fly ash or as a standalone material. One such material which has been identified is Phosphogypsum. Phosphogypsum is produced a s a by-product of fertilizer industry particularly during the production of phosphoric acid. $\quad 120.8 \mathrm{million}$ tons of Phosphogypsum is p r o d u c e d annually out of which substantial amount ends up in landfills. Phosphogypsum is known to cause land degradation and the land may become unsuitable for agriculture. An attempt has been made to produce brick with compressive force resistance capacity in excess of 7.5 $\mathrm{MPa}$ using fly ash and Phosphogypsum. This experiment aims to lower the price of bricks and to reduce the environment impact of these materials which would have ended as landfills. Geo- polymerization has been used to make the bricks. It is a process where Allumino silicate materials like Fly-ash, Phosphogypsum etc. are fused together using alkaline solution.
\end{abstract}

Keywords: Phosphogypsum, Fly-ash, landfills, Environment, Tons, Geo-polymerization, solution, compressive force, resistance, Alkaline solution.

\section{INTRODUCTION}

Carbon dioxide produced as result of cement production is causing environment degradation at an alarming rate. Various countries are taking measure to reduce environment degradation. As a part of this several eco-friendly, alternative method of making construction materials are being encouraged. Approximately 0.815 tons of carbon dioxide per ton of binder is produced during cement clinker production.
Geo-polymer-based bricks present us with a way to replace cement completely. Inorganic Allumino-silicate polymer synthesized from materials containing mainly allumino or silicate-based materials which are formed geologically or as a by-product of fly ash are commonly known as geo-polymers. Geo-polymers are known to produce materials with good compressive strength and can have a wide variety of structural uses. Ceramic like properties help Geo-polymers in achieving high fire resistance. Resistance to fire, acid, sulphate attack, low calcium containing geo-polymers when they are subjected to heat curing. In India, every year 25000 crore masonry bricks are produced by 1.5 lakh kilns; this makes India the second largest producer and consumer of bricks in the world. Most of these kilns use clay for production of bricks. Topsoil has been adversely affected due to the excess utilization of clay in these bricks. There is a huge price variation in these clay bricks due to seasonal variation particularly during monsoon since rains lead to non-validity of clay. Also, Phosphogypsum most of which ends up in landfills is affecting the soil fertility which in turn effects the agriculture productivity of the soil. It is the need of the hour to produce bricks with alternative materials which would also reduce environment degradation. Phosphogypsum and fly ash bricks attempts to address this by proposing alternative materials for bricks, maintaining good structural properties and in some cases much better properties than conventional bricks and at the same time keeping the price less and consistent for most periods of time.

\section{LITERATURE REVIEW}

Duxson. $\mathbf{P}^{1}$ et al., carried out test on coal ash (grade $\mathrm{F}$ and grade C) based geo-polymer concrete and concluded that it exhibits highly gained compressive strength, significant resistance to abrasion, when Polytetrafluoroethylene filler is mixed with it, hardening and setting time is rapidly controllable, up to $1000^{\circ} \mathrm{C}$ fire resistance and when heated it does not emit toxic fumes - this can be pure geo-polymer, geo-polymer composite or carbon fiber based polymer(example; can be a exposed surface coated with geo polymer coatings), acids and salt solutions of different ranges have very less action on it as it offers high level of resistance, alkali-aggregate reactions on 
it is very much less deleterious, low shrinkage and thermal conductivity and shrinkage is very less, it acts as interface between old concrete substrates and fresh concrete and properly adheres to, steel, glass, ceramics high surfaces by replicating mold pattern, chloride diffusion rates are low and residual $\mathrm{P}^{\mathrm{H}}$ is high due to which the steel reinforcement is inherently protected. Joseph Benny ${ }^{2}$ studied fly-ash and alkali activator based geo- polymer concrete, which was cured by heating to a temperature of $100^{\circ} \mathrm{C}$ and it was found out that they exhibit higher engineering properties than ordinary Portland cement. Olivia .M, \& Nikraz. $\mathbf{H}^{\mathbf{3}}$ showed that when compared to ordinary cement concrete geo-polymer concrete showed higher properties like tensile strength, flexural strength, high corrosion resistance, low expansion, and drying shrinkage. Fracture behavior test conducted by Sarker, P. K. ${ }^{4}$ et al., on geo-polymer concrete made using fly-ash showed that geo- polymer had higher stress intensity factor in comparison with normal cement-based concrete. This meant that Geopolymer Concrete would crack at higher load when compared to ordinary cement concrete. Test were conducted by Rangan, B.\& Wallah, Steenie \& Sumajouw, D. \& Hardjito, Djwantoro $^{5}$ et al., on geo-polymer concrete reinforced beams and columns and it was found that it shows good compressive strength and can be used for structural load bearing members. J.Davidovits ${ }^{\mathbf{6}}$ a pioneer in geo-polymer technology and very first proponents of geo-polymer technology through his studies concluded that they are mineral materials which in addition to having a temperature resistance of $1000^{\circ} \mathrm{C}-1200^{\circ} \mathrm{C}$ are hard and have weather resistance, at low temperatures of $30^{\circ} \mathrm{C}$ when they are subjected for a few hours, at $85^{\circ} \mathrm{C}$ when they are subjected for a few minutes, when subjected to microwaves for few seconds they can adopt a shape rapidly by transforming and polycondensation. Cheng, T. $\mathbf{W}^{7}$ studied geo-polymers made with GGBS (Ground granulated blast furnace slag). And the conclusion was that chemical composition plays a vital role in effectingpolymerization behavior, fire resistance, mechanical and other physical properties. $\mathrm{K}_{2} \mathrm{O}$ content plays a considerable role in forming the geo-polymer. When the $\mathrm{K}_{2} \mathrm{O}$ content was increased, fire resistance compressive strength and setting time also increased in proportion to the increased $\mathrm{K}_{2} \mathrm{O}$. Geopolymers based on GGBS can be used in engineering and construction processes. Vijaya Rangan, $\mathbf{B}^{\mathbf{8}}$ from studies on geo-polymer made using GGBS and low-calcium fly-ash concluded that waste products from industries, such as GGBS and fly-ash having low calcium content can be recycled to form geo-polymer with suitable compressive strength and other properties required for structural application and other infrastructure development needs. Hardened reinforced Geo-polymer concrete and ordinary reinforced concrete are having similar elastic properties, strength and other behavioral aspect. Due to this similarity the code of practice IS: 456:2000 which is used for R.C.C can also be used for reinforced Geopolymer. It was also concluded that geo-polymer made using GGBS and low-calcium fly-ash when subjected to heat curing exhibits very little shrinkage on drying, undergoes low creep, shows good acid and fire resistance and has high sulphate attack resistance. Patnaikuni, I. ${ }^{9}$ et al., studied high strength high volume concrete and concluded that 50-70\% replacement of ordinary Portland cement is possible through replacement of cement with fly-ash. B.V. Ramana Prasad ${ }^{10}$ conducted experiments on self-compacting concrete using Phosphogypsum and concluded that when cement is replaced with Phosphogypsum in percentage of 0 to 10 , the compressive strength of concrete increases from $32.08 \mathrm{MPa}$ to 41.50 $\mathrm{MPa}$ and 47.95 $\mathrm{MPa}$ to $52.45 \mathrm{MPa}$ when cured for 7 and 28 days, respectively. When \% percentage of Phosphogypsum is increased from $10 \%$ to $30 \%$ it causes decrease in compressive strength of concrete from 41.50 $\mathrm{MPa}$ to 19.20 $\mathrm{MPa}$ and from 52.45 MPa to 25.15 MPa when cured for 7 and 28 days respectively. The split tensile strength of concrete increase from $3.50 \mathrm{MPa}$ to $3.61 \mathrm{MPa}$ when cement is replaced by Phosphogypsum in percentages varying between 0 to 10 . When Cement is replaced with Phosphogypsum in percentages between 10 to 30 it causes decrease in split tensile strength of concrete from 3.61 MPa to 2.15 MPa. When cement is replaced with Phosphogypsum in percentages of $0 \%$ to $10 \%$ the flexural strength of concrete increases from 4.92 $\mathrm{MPa}$ to $6.74 \mathrm{MPa}$. When cement is replaced by Phosphogypsum in percentages varying between 10 to 30 , the flexural strength of concrete decreases from 6.74 MPa to 2.92 MPa. When Phosphogypsum replaces cement in percentages of 20 and 30 the crack width and no of cracks are increased. Manoj Kumar Manugunta\&Naveena Kanaboyana ${ }^{11}$ from their experiments on strength of Geopolymer mortar based on Fly-ash and GGBS concluded that when GGBS content increases the compressive strength also increases. After 7 days of curing the compressive strength are in the range of $1.163-33.59 \mathrm{~N} / \mathrm{mm}^{2}$ depending on GGBS content. The flow of mortar is very dry and exhibits greater percentage of flow for $\mathrm{F} / \mathrm{B}$ ratios of 0.40 and 0.45 respectively. The compressive strength increases with age for all proportions, but maximum strength is obtained when F/B ratio is 0.45 at 7 days when combination of $80 \%$ GGBS and 20 $\%$ fly ash in used.

\section{TOOLS AND MATERIALS USED}

Tools:

Brick molds of size: $90 \mathrm{~mm}$ x $92 \mathrm{~mm}$ x $192 \mathrm{~mm}$. Compression testing machine of 100 tons capacity. Heating Oven up to $500^{0} \mathrm{C}$.

Concrete mixer 1 bag capacity.

Water hardness meter.

$\mathbf{P}^{\mathbf{H}}$ meter.

\section{Materials/chemicals}

Flv-ash: finely ground, conforming to Grade 2 of IS 3812 (60$65 \%$ ), has been sourced from Ramagundam NTPC Thermal power plant.

Ash collected by the use of electrostatic precipitators is called fly-ash. Coal combustion produces fly-ash as its by-product. When flue gases are driven out of coal-fired boilers particulates are formed, these particulates form fly-ash.

Phosphogvpsum: Finely ground without lumps or clinkers has been sourced from coromandel fertilizers Kakinada, Phosphogypsum contains $18 \%$ Suplhur,22 \% Calcium and 3$4 \%$ moisture. (see Fig 1). 


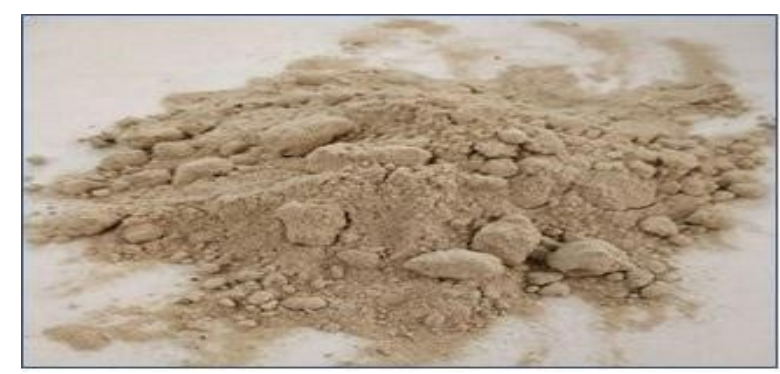

Fig 1: PHOSPHOGYPSUM

Coarse aggregate (stones chips): small size stone chips that are retained on 4.75 MM IS sieve as per IS 383:1970. Specific Gravity of coarse aggregate being used is 2.8 .

Fine Aggregate (sand): River sand of grain size such that it passes IS sieve of size $4.75 \mathrm{~mm}$ as per IS 383: 1970.Specific Gravity of fine aggregate being used is 2.65 .

Calcium sulphate hydrate formed as a by-product of the production of phosphoric acid fertilizer from phosphate rock is referred to as Phosphogypsum. It is mainly composed of gypsum $\left(\mathrm{CaSO}_{4} \cdot 2 \mathrm{H}_{2} \mathrm{O}\right)$. Though gypsum is conventionally used in construction industry, Phosphogypsum is not being widely used but due to its weak radioactivity, it is widely stored indefinitely which has been controversial.

Caustic soda is the common name of Sodium Hydroxide. At ordinary ambient temperatures it can cause decomposition of protein. Chemical burns of high severity may be caused by NaoH. It has high water solubility, carbon dioxide and moisture from the air are instantly absorbed by it. Hydrate series of the type $\mathrm{NaOH} \cdot \mathrm{nH}$ are formed by $\mathrm{NaOH}$. When $\mathrm{NaOH}$ is dissolved in water a large amount of heat is released as it is a highly exothermic reaction. Sufficient amount of care needs to be taken to avoid injury.

Sodium Hydroxide (NaoH). $99 \%$ lab grade sodium hydroxide pellets have been used.10 M sodium hydroxide solution is used. (see Fig:2).

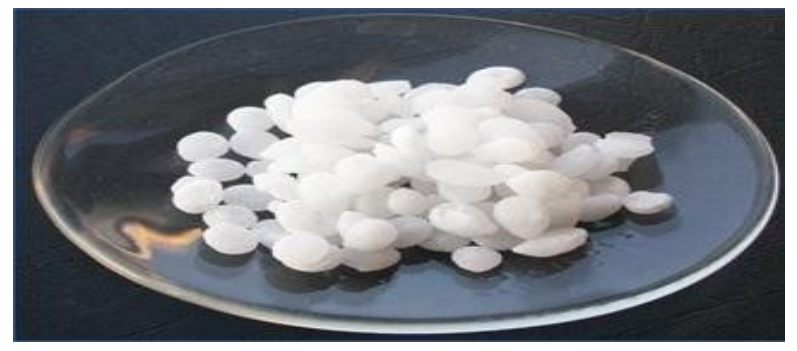

Fig 2: SODIUM HYDROXIDE PELLETS

Sodium Silicate (Na2Sio3). $10 \mathrm{M}$ sodium silicate solution is used. (see Fig .3)

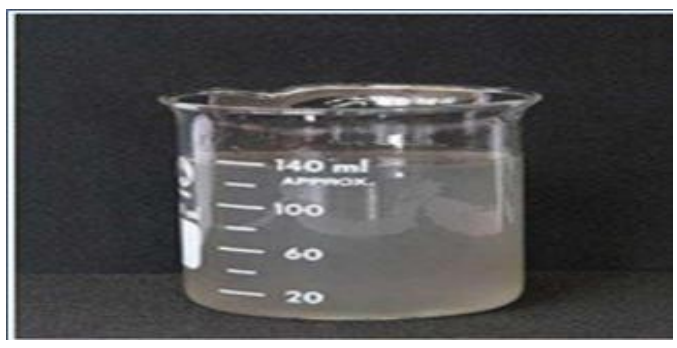

Fig. 3: SODIUM SILICATE SOLUTION
An inorganic sodium salt having silicate as the counterion. It is commonly known as water glass. It is a transparent substance which is sticky in nature. Other types of $\mathrm{Na}$ and silicate combinations such as sodium-metasilicate, sodiumorthosilicate, and sodium-pyro silicate are also commonly formed compounds.

\section{METHODOLOGY}

All tests are done in accordance with provisions of IS : 3495.parts 1-4.

Firstly, alkaline solutions are made by mixing Sodium Hydroxide $(\mathrm{NaOH})$ and Sodium Silicate $\left(\mathrm{Na}_{2} \mathrm{Sio} 3\right)$. Several mixtures are made by adding Phosphogypsum, coarseaggregate, fine-aggregate and fly-ash in various proportions. Some mixtures are also made without fly-ash. To the resulting mixtures the alkaline solutions of various proportions are added. The resulting mixture are thoroughly mixed in a concrete mixture. The mixed materials are poured into brick mold and bricks are made. The bricks made are cured in oven for 12 hours at a temperature between $70-75^{\circ} \mathrm{C}$. The oven cured bricks are subjected to various standard brick tests.

A solution of sodium-hydroxide and sodium silicate of 10M, as per the pre-defined proportion is made and kept aside. Phosphogypsum is weighed as per pre-defined proportion and added to the concrete mixer. Then fly-ash is weighed as per predefined proportion and added to the concrete mixer. Similarly, first fine-aggregate(sand) and then coarse aggregate are weighed as per pre-defined proportions and added. To this mix the previously prepared solution of Sodium-hydroxide and Sodium-silicate is added. All the materials are thoroughly mixed in the concrete mixer for 30-45 minutes. This results in a semi solid mixture. This mixture is then poured into brick mold and casted into bricks. The resulting bricks are cured at in temperature between $70-75^{\circ} \mathrm{C}$ for 12 hours in an oven. After curing the bricks are removed and subjected to various tests. In some cases, bricks are made and tested without the use of flyash. In such case the entire procedure remains the same, without the addition of fly-ash.

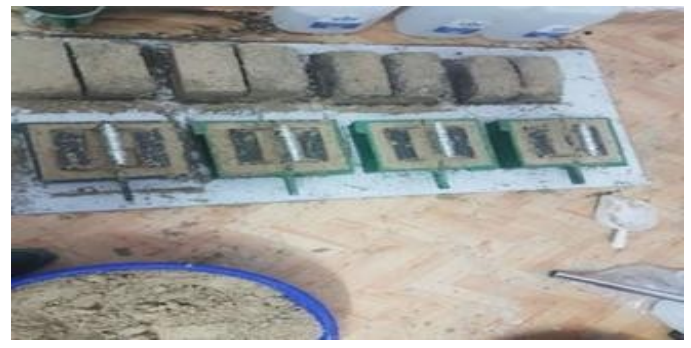

Fig 4: BRICK CASTING

\section{Compressive test procedure:}

Crushing strength of bricks is determined by placing brick in compression testing machine. After placing the brick in compression testing machine, apply load on it until brick breaks. Note down the value of failure load and find out the crushing strength value of brick. Minimum crushing strength of brick is $3.50 \mathrm{~N} / \mathrm{mm}^{2}$.if it is less than $3.50 \mathrm{~N} / \mathrm{mm}^{2}$, then it is not useful for construction purpose. 


\section{Water Absorbtion test:}

The purpose of this test is to ascertain how much percentage of moisture can be absorbed by the brick under extreme conditions.

Weight of dry Brick is first obtained. The brick is then immersed in distilled water of $\mathrm{P}^{\mathrm{H}}=7$, for 24 hours, then taken out and weighed. If the difference in weight of dry brick and water absorbed brick is not more than 20 percent of the weight of dry brick, then such a brick is said to have passed the water absorbtion test and is deemed to be suitable for construction. (fig 5.)

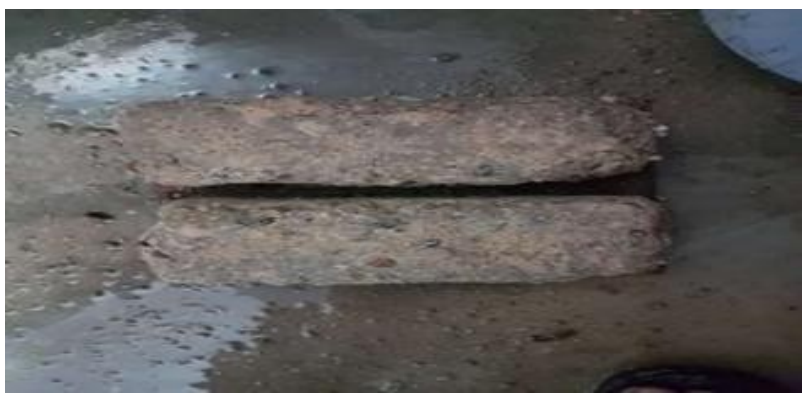

Fig 5: BRICKS, AFTER 24 HOURS SUBMERGED IN WATER. (WATER ABSORBTION TEST.)

\section{Acid Reaction test:}

Brick are immersed in concentrated Hydrochloric Acid of $\mathrm{PH}=7$ and $1 \mathrm{M}$ molarity, for 24 hours, then taken out and all the standard test on bricks are conducted. Despite reaction with acid if the brick still exhibits the requisite characteristics as desired by each test, then the brick is said to have passed the acid reaction test and is deemed to be suitable for construction. (fig 6.)

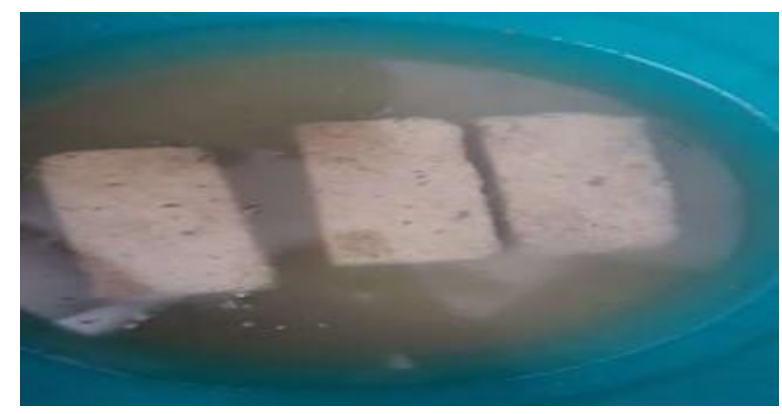

Fig 6: BRICKS, AFTER 24 HOURS SUBMERGED IN ACID. (ACID REACTION TEST.)

\section{Mix proportions tried:}

The proportion of Phosphogypsum, Fly-ash, Fine aggregate and coarse aggregate are varied from $9 \%$ to $25 \%$ in $1 \%$ interval increments.

\section{Mix proportions sample calculations: \\ With Phosphogypsum and Fly-ash:}

The percentage of Phosphogypsum in $\operatorname{mix}=9.00 \%$.

All other materials like Fly-ash, Fine aggregate, Coarse, aggregate, Sodium-Hydroxide and Sodium-Silicate are mixed in equal percentage of remaining proportion.

$$
\begin{aligned}
& \% \text { of fly-ash }=(100-9) / 5=18.2 \% \text {. } \\
& \% \text { of other materials is also calculated in similar way. }
\end{aligned}
$$

$\%$ of all materials in the mix = PHOSPHOGYPSUM: FLY ASH: FINE AGGREGATE: COARSE- AGGREGATE: SODIUM-HYDROXIDE: SODIUM-SILCATE) = 9:18.2:18.2:18.2:18.2:18.2

\section{Dividing by 9}

Proportions = PHOSPHOGYPSUM: FLY ASH: FINE AGGREGATE: COARSE- AGGREGATE: SODIUMHYDROXIDE:

1:2.02:2.02:2.02:2.02:2.02 SODIUM-SILCATE):

\section{With Phosphogypsum and without Fly-ash:}

The percentage of Phosphogypsum in $\operatorname{mix}=9.00 \%$.

All other materials like Fine aggregate, Coarse, aggregate, Sodium-Hydroxide and Sodium-Silicate are mixed in equal percentage of remaining proportion.

$\%$ of fine-aggregate $=(100-9) / 4=22.75 \%$.

$\%$ of other materials is also calculated in similar way.

$\%$ of all materials in the mix = PHOSPHOGYPSUM: FINE AGGREGATE: COARSE-AGGREGATE: SODIUMHYDROXIDE: SODIUM-SILCATE) = 9: 22.75: 22.75: 22.75: 22.75

Dividing by 9

Proportions = PHOSPHOGYPSUM: FINE-AGGREGATE: COARSE AGGREGATE: SODIUM-HYDROXIDE: SODIUM-SILCATE): $1: 2.53: 2.53: 2.53: 2.53: 2.53$

\section{Codal provisions:}

The average compressive strength of brick as per clause 7.1 of IS:1707:1992 (2002) Indian Standard Code of Practice Common brunt clay building bricks-specification. $5^{\text {th }}$ Edition, Bureau of Indian Standards, New Delhi., shall be at least :105 $\mathrm{kg} / \mathrm{cm}^{2}$ for first-class bricks, $75 \mathrm{~kg} / \mathrm{cm}^{2}$ for second-class bricks, $35 \mathrm{~kg} / \mathrm{cm}^{2}$ for common building brick and $15 \mathrm{~kg} / \mathrm{cm}^{2}$ to $25 \mathrm{~kg} / \mathrm{cm}^{2}$ for sun-dried brick.

The water absorption as per clause 7.2 of IS:1707:1992 (2002) Indian Standard Code of Practice Common brunt clay building bricks-specification. $5^{\text {th }}$ Edition, Bureau of Indian Standards, New Delhi., shall not more than 20 percent by weight for class of brick up to 12.5 and not more than 15 percent for higher classes above 12.5 
Table 1: Mix Proportions for Oven Dried Brick Mixes.

\begin{tabular}{|c|c|c|c|c|c|}
\hline $\begin{array}{l}0 \\
z \\
\ddot{n}\end{array}$ & 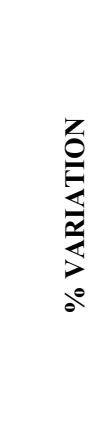 & 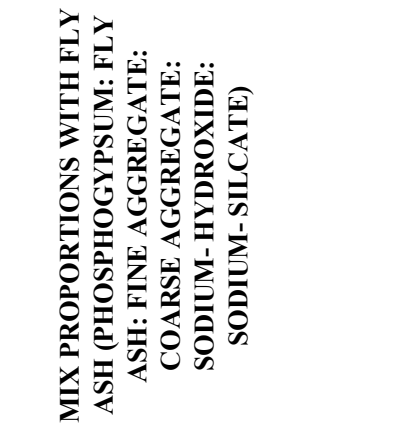 & 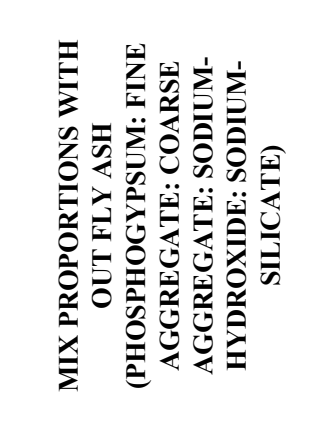 & 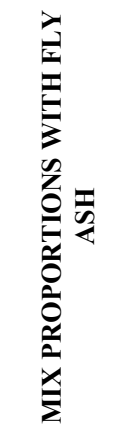 & 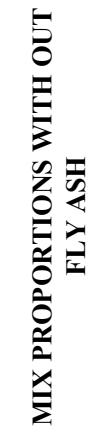 \\
\hline \multicolumn{6}{|c|}{ PHOSPHOGYPSUM PERCENTAGE VARIATION } \\
\hline 1 & 9.00 & $1: 2.02: 2.02: 2.02: 2.02: 2.02$ & $1: 2.53: 2.53: 2.53: 2.53$ & OMPF1 & OMP18 \\
\hline 2 & 10.00 & $1: 1.8: 1.8: 1.8: 1.8: 1.8$ & $1: 2.25: 2.25: 2.25: 2.25$ & OMPF2 & OMP19 \\
\hline 3 & 11.00 & $1: 1.62: 1.62: 1.62: 1.62: 1.62$ & $1: 2.02: 2.02: 2.02: 2.02$ & OMPF3 & OMP20 \\
\hline 4 & 12.00 & $1: 1.47: 1.47: 1.47: 1.47: 1.47$ & $1: 1.83: 1.83: 1.83: 1.83$ & OMPF4 & OMP21 \\
\hline 5 & 13.00 & $1: 1.34: 1.34: 1.34: 1.34: 1.34$ & $1: 1.67: 1.67: 1.67: 1.67$ & OMPF5 & OMP22 \\
\hline 6 & 14.00 & $1: 1.23: 1.23: 1.23: 1.23: 1.23$ & $1: 1.54: 1.54: 1.54: 1.54$ & OMPF6 & OMP23 \\
\hline 7 & 15.00 & $1: 1.13: 1.13: 1.13: 1.13: 1.13$ & $1: 1.42: 1.42: 1.42: 1.42$ & OMPF7 & OMP24 \\
\hline 8 & 16.00 & $1: 1.05: 1.05: 1.05: 1.05: 1.05$ & $1: 1.31: 1.31: 1.31: 1.31$ & OMPF8 & OMP25 \\
\hline 9 & 17.00 & $1: 0.98: 0.98: 0.98: 0.98: 0.98$ & $1: 1.22: 1.22: 1.22: 1.22$ & OMPF9 & OMP26 \\
\hline 10 & 18.00 & $1: 0.91: 0.91: 0.91: 0.91: 0.91$ & $1: 1.14: 1.14: 1.14: 1.14$ & OMPF10 & OMP27 \\
\hline 11 & 19.00 & $1: 0.85: 0.85: 0.85: 0.85: 0.85$ & $1: 1.07: 1.07: 1.07: 1.07$ & OMPF11 & OMP28 \\
\hline 12 & 20.00 & $1: 0.8: 0.8: 0.8: 0.8: 0.8$ & $1: 1: 1: 1: 1$ & OMPF12 & OMP29 \\
\hline 13 & 21.00 & $1: 0.75: 0.75: 0.75: 0.75: 0.75$ & $1: 0.94: 0.94: 0.94: 0.94$ & OMPF13 & OMP30 \\
\hline 14 & 22.00 & $1: 0.71: 0.71: 0.71: 0.71: 0.71$ & $1: 0.89: 0.89: 0.89: 0.89$ & OMPF14 & OMP31 \\
\hline 15 & 23.00 & $1: 0.67: 0.67: 0.67: 0.67: 0.67$ & $1: 0.84: 0.84: 0.84: 0.84$ & OMPF15 & OMP32 \\
\hline 16 & 24.00 & $1: 0.63: 0.63: 0.63: 0.63: 0.63$ & $1: 0.79: 0.79: 0.79: 0.79$ & OMPF16 & OMP33 \\
\hline 17 & 25.00 & $1: 0.6: 0.6: 0.6: 0.6: 0.6$ & $1: 0.75: 0.75: 0.75: 0.75$ & OMPF17 & OMP34 \\
\hline \multicolumn{6}{|c|}{ FLY-ASH PERCENTAGE VARIATION } \\
\hline 18 & 9.00 & $2.02: 1: 2.02: 2.02: 2.02: 2.02$ & -- & OMFF35 & -- \\
\hline 19 & 10.00 & $1.8: 1: 1.8: 1.8: 1.8: 1.8$ & -- & OMFF36 & --- \\
\hline 20 & 11.00 & $1.62: 1: 1.62: 1.62: 1.62: 1.62$ & --- & OMFF37 & --- \\
\hline 21 & 12.00 & $1.47: 1: 1.47: 1.47: 1.47: 1.47$ & --- & OMFF38 & --- \\
\hline 22 & 13.00 & $1.34: 1: 1.34: 1.34: 1.34: 1.34$ & -- & OMFF39 & -- \\
\hline 23 & 14.00 & $1.23: 1: 1.23: 1.23: 1.23: 1.23$ & -- & OMFF40 & -- \\
\hline 24 & 15.00 & $1.13: 1: 1.13: 1.13: 1.13: 1.13$ & -- & OMFF41 & -- \\
\hline 25 & 16.00 & $1.05: 1: 1.05: 1.05: 1.05: 1.05$ & -- & OMFF42 & -- \\
\hline 26 & 17.00 & $0.98: 1: 0.98: 0.98: 0.98: 0.98$ & --- & OMFF43 & -- \\
\hline 27 & 18.00 & $0.91: 1: 0.91: 0.91: 0.91: 0.91$ & -- & OMFF44 & -- \\
\hline 28 & 19.00 & $0.85: 1: 0.85: 0.85: 0.85: 0.85$ & -- & OMFF45 & --- \\
\hline 29 & 20.00 & $0.8: 1: 0.8: 0.8: 0.8: 0.8$ & --- & OMFF46 & -- \\
\hline 30 & 21.00 & $0.75: 1: 0.75: 0.75: 0.75: 0.75$ & -- & OMFF47 & -- \\
\hline 31 & 22.00 & $0.71: 1: 0.71: 0.71: 0.71: 0.71$ & --- & OMFF48 & --- \\
\hline 32 & 23.00 & $0.67: 1: 0.67: 0.67: 0.67: 0.67$ & -- & OMFF49 & -- \\
\hline 33 & 24.00 & $0.63: 1: 0.63: 0.63: 0.63: 0.63$ & --- & OMFF50 & --- \\
\hline 34 & 25.00 & $0.6: 1: 0.6: 0.6: 0.6: 0.6$ & --- & OMFF51 & --- \\
\hline
\end{tabular}


International Journal of Engineering Research and Technology. ISSN 0974-3154, Volume 13, Number 6 (2020), pp. 1330-1343 (C) International Research Publication House. https://dx.doi.org/10.37624/IJERT/13.6.2020.1330-1343

\section{RESULTS AND DISCUSSIONS:}

The results obtained for different bricks properties for different Phosphogypsum percentages are presented in table 2 below.

Table 2: Oven-Cured Brick: \% of Phosphogypsum vs Brick Properties

\begin{tabular}{|c|c|c|c|c|c|c|c|c|c|c|}
\hline $\begin{array}{l}\dot{0} \\
Z \\
\dot{\sigma}\end{array}$ & $\begin{array}{l}Z \\
\sum \\
\vdots \\
0 \\
0 \\
0 \\
0 \\
0 \\
0 \\
0 \\
0 \\
0 \\
0 \\
0 \\
0 \\
0 \\
0 \\
0 \\
0 \\
0 \\
0\end{array}$ & 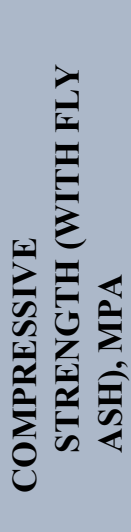 & 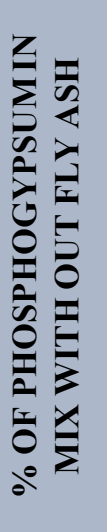 & 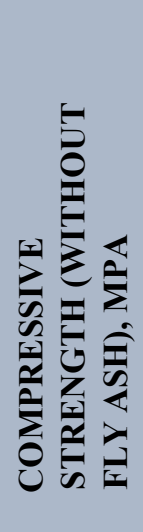 & 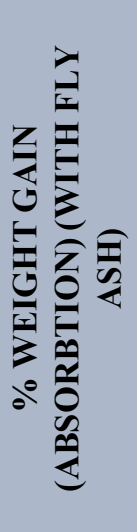 & 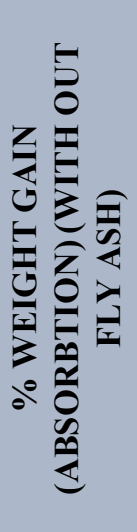 & 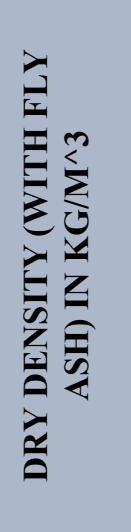 & 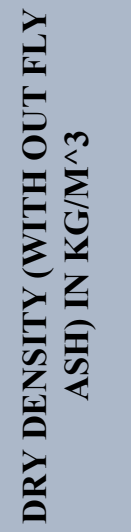 & 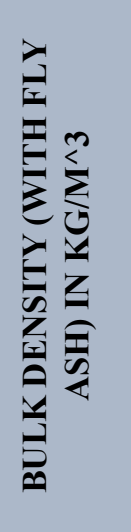 & 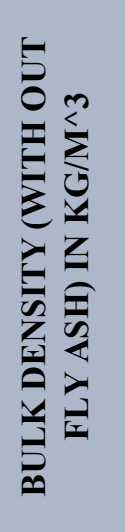 \\
\hline 1 & 9.00 & 20.31 & 9.00 & 17.11 & 17.81 & 17.17 & 1670.36 & 2010.36 & 1967.84 & 2312.18 \\
\hline 2 & 10.00 & 21.78 & 10.00 & 18.12 & 17.61 & 17.77 & 1669.79 & 2000.22 & 1963.85 & 2280.23 \\
\hline 3 & 11.00 & 22.65 & 11.00 & 18.91 & 17.56 & 18.05 & 1669.16 & 1998.34 & 1962.24 & 2270.67 \\
\hline 4 & 12.00 & 22.95 & 12.00 & 19.11 & 17.73 & 18.17 & 1668.46 & 1968.88 & 1964.21 & 2262.92 \\
\hline 5 & 13.00 & 23.13 & 13.00 & 19.18 & 17.68 & 18.28 & 1667.69 & 1908.22 & 1962.48 & 2259.92 \\
\hline 6 & 14.00 & 23.06 & 14.00 & 20.37 & 17.66 & 18.62 & 1666.82 & 1905.59 & 1961.29 & 2260.28 \\
\hline 7 & 15.00 & 22.85 & 15.00 & 20.97 & 17.66 & 18.68 & 1665.85 & 1902.63 & 1960.03 & 2258.03 \\
\hline 8 & 16.00 & 22.49 & 16.00 & 21.11 & 17.68 & 18.66 & 1664.75 & 1899.27 & 1959.07 & 2253.67 \\
\hline 9 & 17.00 & 21.95 & 17.00 & 21.08 & 17.70 & 18.64 & 1663.49 & 1895.43 & 1957.83 & 2248.79 \\
\hline 10 & 18.00 & 21.27 & 18.00 & 21.04 & 17.67 & 18.67 & 1662.03 & 1891.00 & 1955.73 & 2244.10 \\
\hline 11 & 19.00 & 20.49 & 19.00 & 21.10 & 17.68 & 18.67 & 1660.33 & 1885.83 & 1953.81 & 2237.92 \\
\hline 12 & 20.00 & 19.58 & 20.00 & 21.15 & 17.69 & 18.67 & 1658.33 & 1879.73 & 1951.64 & 2230.64 \\
\hline 13 & 21.00 & 18.60 & 21.00 & 20.99 & 17.67 & 18.69 & 1655.92 & 1872.40 & 1948.39 & 2222.35 \\
\hline 14 & 22.00 & 17.56 & 22.00 & 20.70 & 17.57 & 18.64 & 1652.98 & 1863.44 & 1943.38 & 2210.84 \\
\hline 15 & 23.00 & 16.38 & 23.00 & 19.42 & 17.61 & 18.68 & 1649.30 & 1852.25 & 1939.69 & 2198.29 \\
\hline 16 & 24.00 & 15.22 & 24.00 & 18.73 & 18.18 & 18.69 & 1644.57 & 1837.86 & 1942.80 & 2181.36 \\
\hline 17 & 25.00 & 15.13 & 25.00 & 17.45 & 18.47 & 18.75 & 1622.17 & 1818.67 & 1942.80 & 2157.92 \\
\hline
\end{tabular}


International Journal of Engineering Research and Technology. ISSN 0974-3154, Volume 13, Number 6 (2020), pp. 1330-1343

(C) International Research Publication House. https://dx.doi.org/10.37624/IJERT/13.6.2020.1330-1343

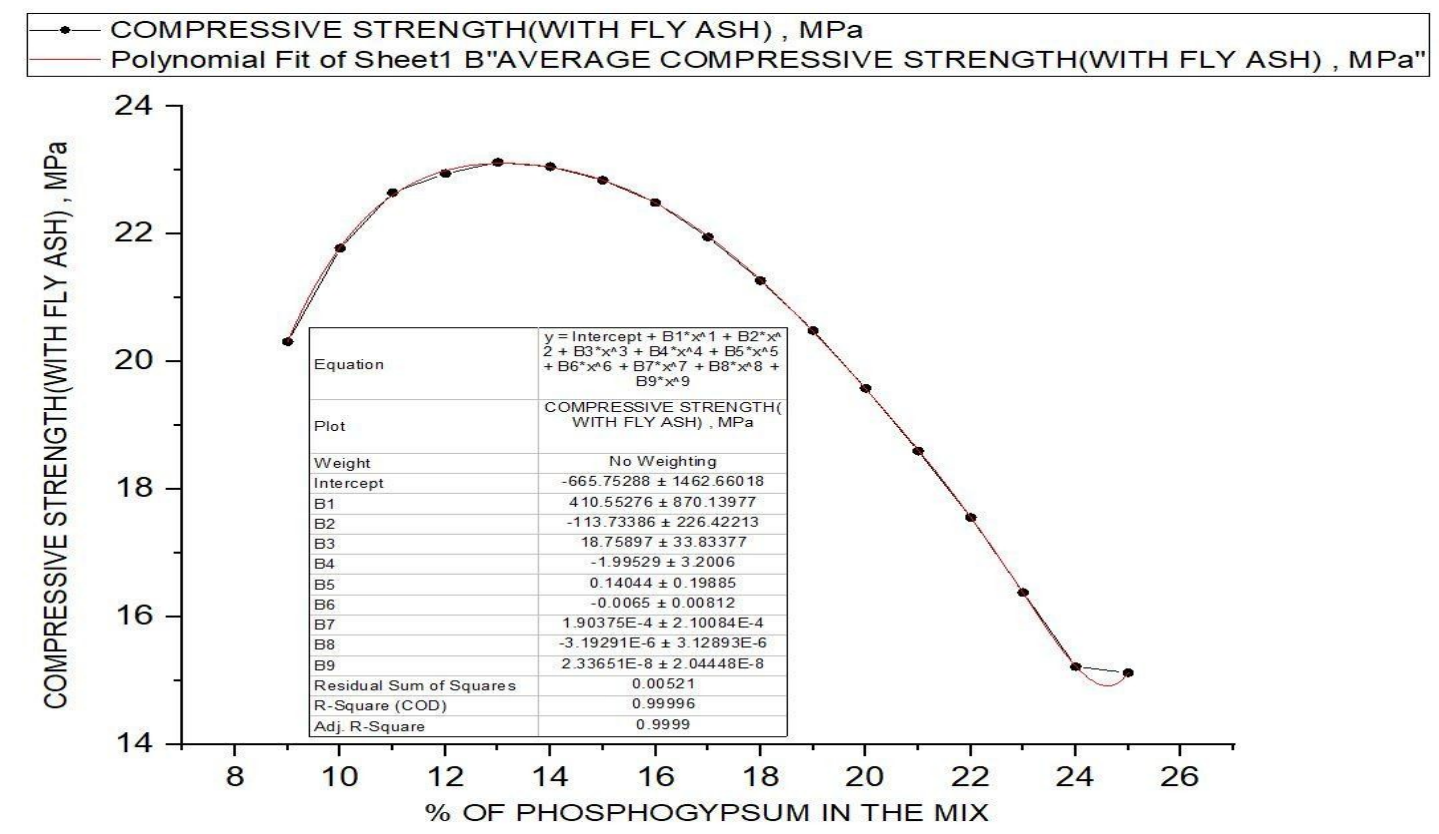

Fig 7: Variation of Compressive Strength with percentage of Phosphogypsum for Bricks with Fly Ash

From Fig 7 and table 2, it is inferred that, in case of oven dried sample with the use of fly-ash, the increase in percentage of Phospho-gypsum from $9 \%$ to $13 \%$ causes an increase in average compressive strength from $20.31 \mathrm{MPa}$ to $23.13 \mathrm{MPa}$ when cured in an oven for 12 hours at a temperature of $70^{0}$ $\mathrm{C}-75^{0} \mathrm{C}$. Further increase in Phospho-gypsum $\%$ from $14 \%$ to $25 \%$ causes decrease in compressive strength from 23.06 $\mathrm{MPa}$ to $15.13 \mathrm{MPa}$ when cured in an oven for 12 hours at a temperature of $70^{0} \mathrm{C}-75^{0} \mathrm{C}$. This may be due to the fact that other compounds in the mix also may play a dominant role. The highest and lowest compressive strengths recorded are 23.13 MPa and 15.22 MPa corresponding to Phosphogypsum percentages of 13 and 25 respectively. The mean Compressive strength recorded is $21.95 \mathrm{MPa}$ corresponding to Phosphogypsum percentage of 17.

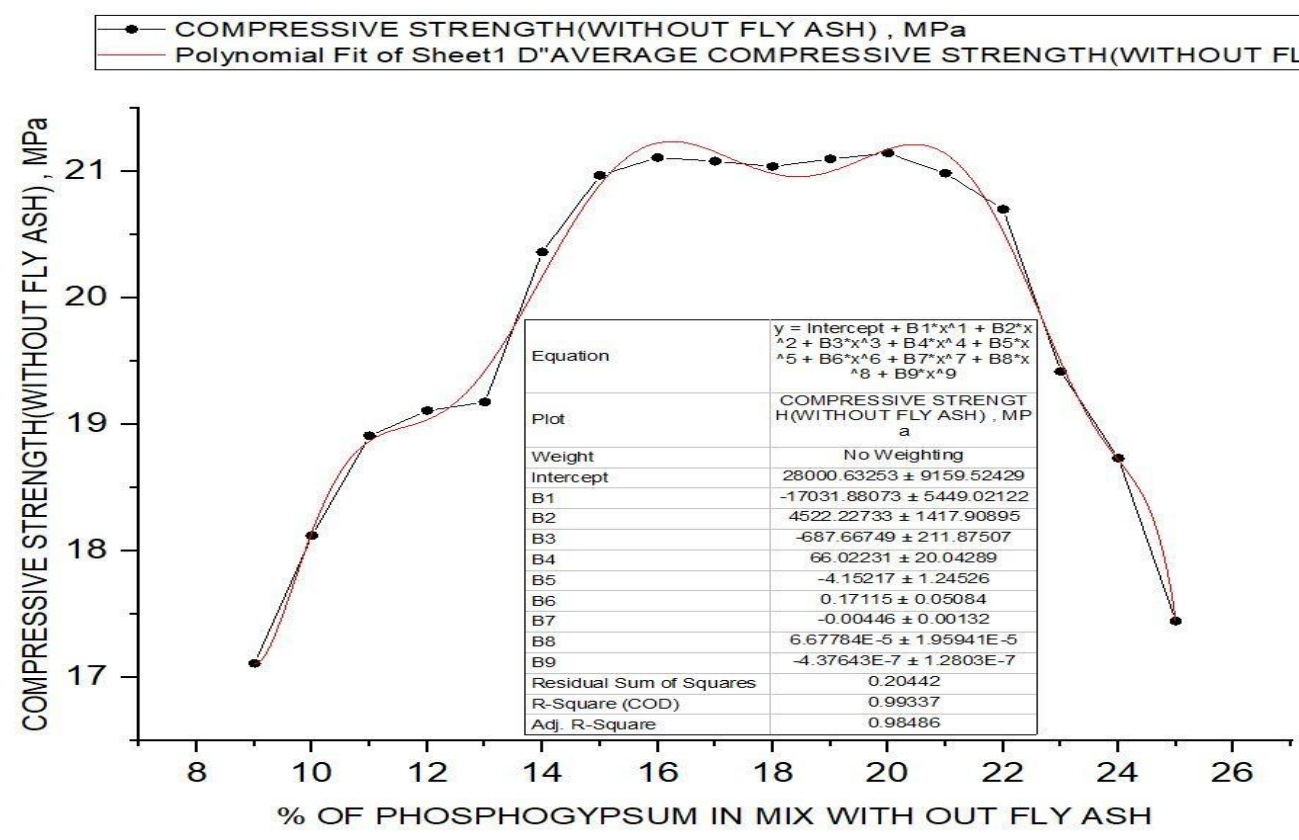

Fig 8: Variation of Compressive Strength with percentage of Phosphogypsum for Bricks without Fly Ash

From Fig 8 and table 2, it is inferred that, in case of oven dried sample without fly- ash the increase in percentage of
Phosphogypsum from $9 \%$ to $16 \%$ causes an increase in compressive strength from $17.11 \mathrm{MPa}$ to $21.11 \mathrm{MPa}$ when 
cured in an oven for 12 hours at a temperature of $70^{0} \mathrm{C}-75^{0}$ C. Further increase in Phosphogypsum percentage from $17 \%$ to $25 \%$ causes decrease in compressive strength from 21.08 $\mathrm{MPa}$ to $17.45 \mathrm{MPa}$. The only exception to this is encountered at Phosphogypsum percentage of 20 where the compressive strength suddenly increases to $21.15 \mathrm{MPa}$. The highest and lowest compressive strengths recorded are $21.15 \mathrm{MPa}$ and 17.45 $\mathrm{MPa}$ corresponding to Phosphogypsum percentages of 20.00 and 25.00, respectively. The mean Compressive strength recorded is $21.08 \mathrm{MPa}$ corresponding to Phosphogypsum percentage of 17 .

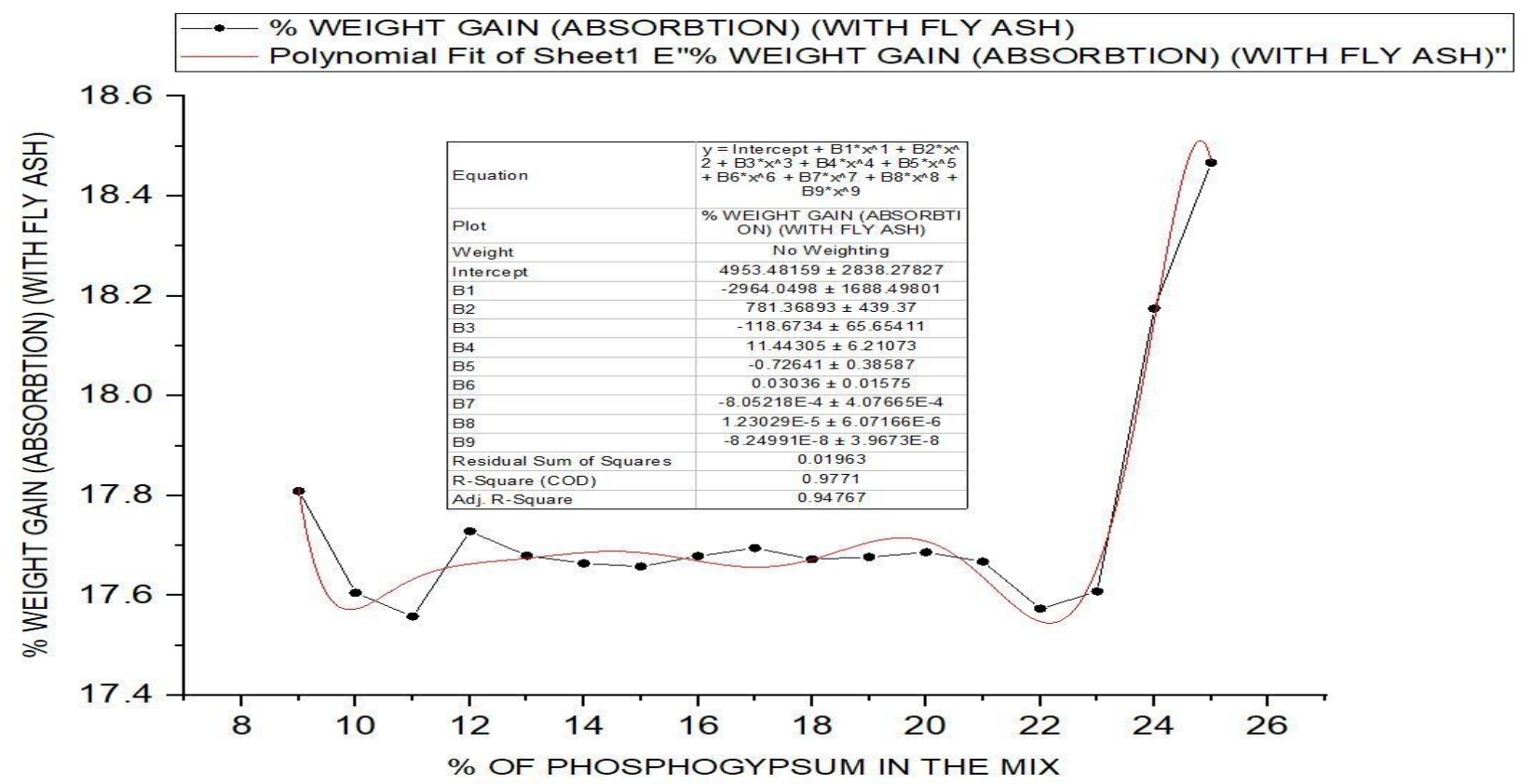

Fig 9: Percentage of Phosphogypsum (with Fly Ash) vs Percentage Weight Gain (Absorbtion) (with Fly Ash)

From Fig 9 and table 2, it is inferred that, in case of oven dried sample with the use of fly-ash, the increase in percentage of Phospho-gypsum from $9 \%$ to $13 \%$ does-not have a profound effect on water absorbtion and remains the same with very little random variation. When Phosphogypsum percentage increases from $22 \%$ to $25 \%$ the water abortion increases from $17.61 \%$ to $18.47 \%$. The highest and lowest water absorbtion percentages being 18.47 and 17.56 , corresponding to phospho-gypsum percentages of 25.00 and 11.00 , respectively.

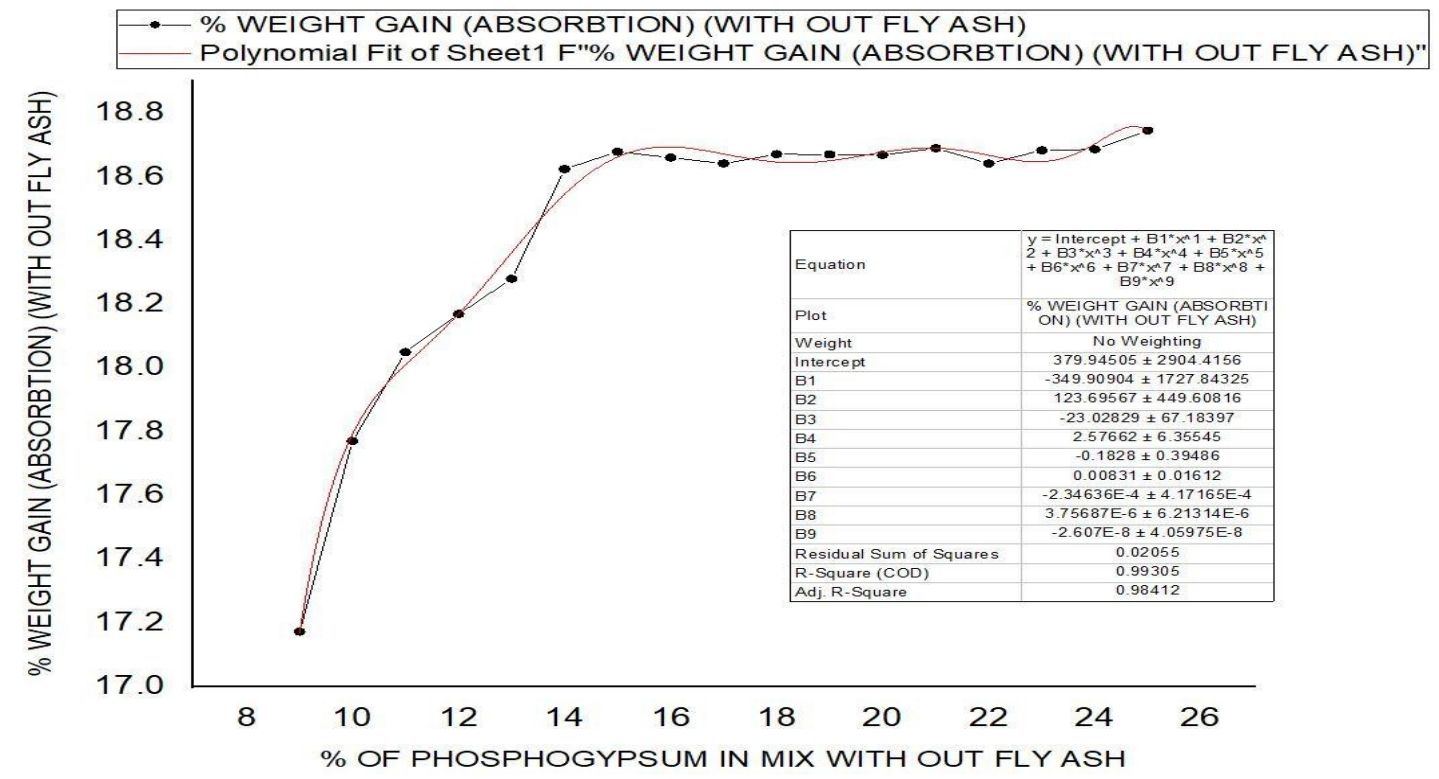

Fig 10: Variation of water absorbtion with percentage of Phosphogypsum for Bricks without Fly Ash 
From Fig 10 and table 2, it is inferred that, in case of oven dried sample without fly- ash the increase in percentage of Phospho-gypsum does-not have a profound effect on water absorbtion and remains the same with very little random variation. The highest and lowest water absorbtion percentages being 18.75 and 17.17 , corresponding to Phospho-gypsum percentages of 25.00 and 9.00, respectively. When Phospho-gypsum percentages increases from $9 \%$ to $15 \%$ the water absorbtion increases from $17.17 \%$ to $18.68 \%$. When Phosphogypsum percentages increases further from 17 $\%$ to $25 \%$ the water absorbtion increases from $18.64 \%$ to $18.75 \%$. At Phosphogypsum percentages of $16 \%$ and $22 \%$, the water absorbtion falls to values of $18.66 \%$ and $18.64 \%$ respectively.
It is observed that the water absorbtion is more when no fly-ash is used than when fly -ash is used in the mix, this may be due to the fact that Phosphogypsum is hydrophilic and absorbs more water, whereas fly-ash is hydrophobic and absorbs less water. In either case with or without fly-ash the water absorbtion is within the limits of $20 \%$ as prescribed in standard test for bricks as per IS:1707:1992 (2002) Indian Standard Code of Practice Common brunt clay building bricksspecification. $5^{\text {th }}$ Edition, Bureau of Indian Standards, New Delhi.

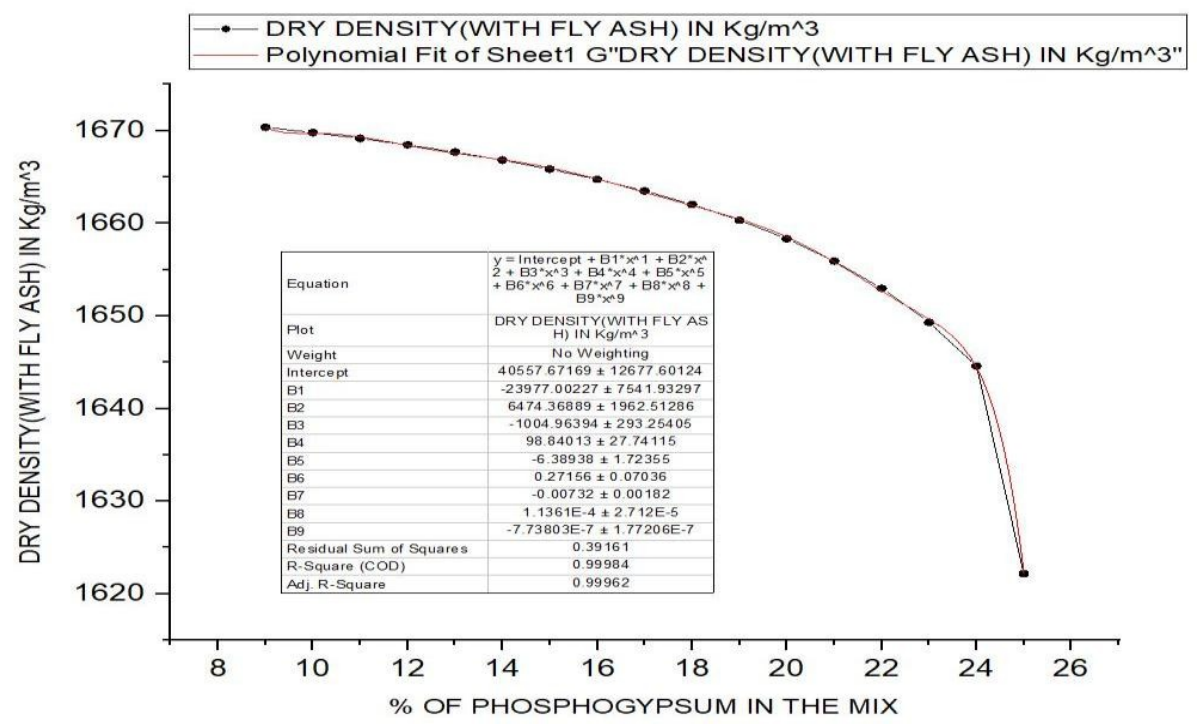

Fig 11: Variation of dry density with percentage of Phosphogypsum for Bricks with Fly Ash

From Fig 11 and table 2, it is inferred that, in case of oven dried sample with the use of fly-ash, increase in Phosphogypsum percentage from $9 \%$ to $25 \%$ causes the dry density to decrease from $1670.36 \mathrm{Kg} / \mathrm{m}^{3}$ to $1622.17 \mathrm{Kg} / \mathrm{m}^{3}$.

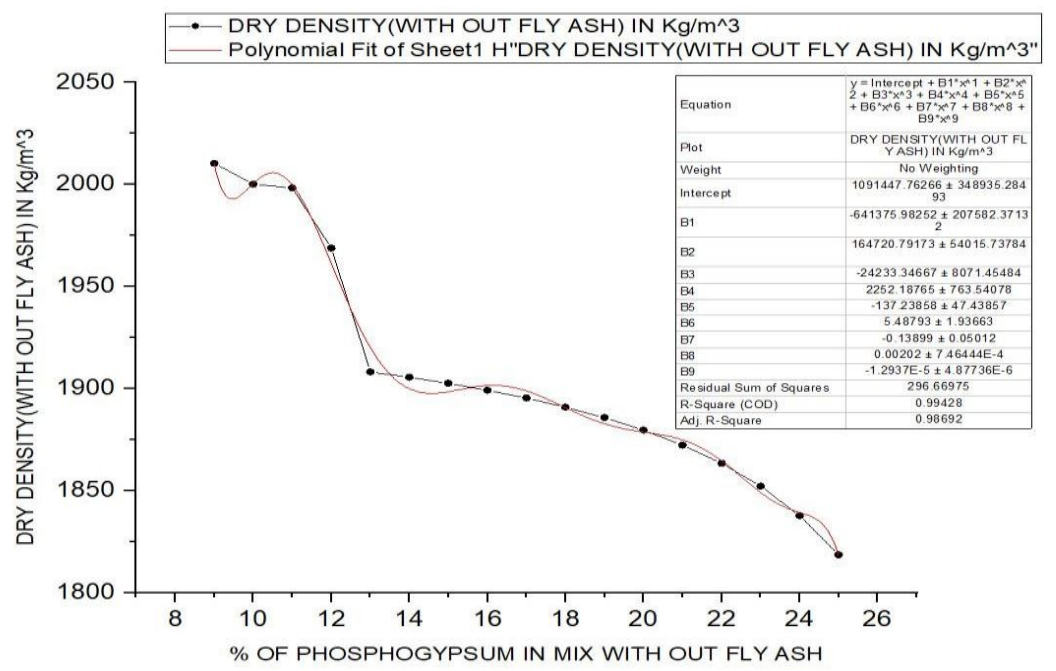

Fig 12: Variation of dry density with percentage of Phosphogypsum for Bricks without Fly Ash 
From Fig 12 and table 2, it is inferred that, in case of oven dried sample without fly-ash the increase in Phosphogypsum percentage from 9 to 25 causes decrease in dry density from $2010.36 \mathrm{Kg} / \mathrm{m}^{3}$ to $1818.67 \mathrm{Kg} / \mathrm{m}^{3}$. With the lowest and highest densities being $1818.67 \mathrm{Kg} / \mathrm{m}^{3}$ and $2010.36 \mathrm{Kg} / \mathrm{m}^{3}$ corresponding to Phosphogypsum percentages of 25.00 and 9.00 respectively.
The dry density is higher when not using fly-ash than when using fly-ash, this may be due to the fact that fly-ash being highly voluminous i.e. it occupies a large space, but its weight is very less. The dry density of first-class brick is 2100 $\mathrm{Kg} / \mathrm{m}^{3}$ when comparing to this value the dry densities are lesser whether using fly-ash or not.

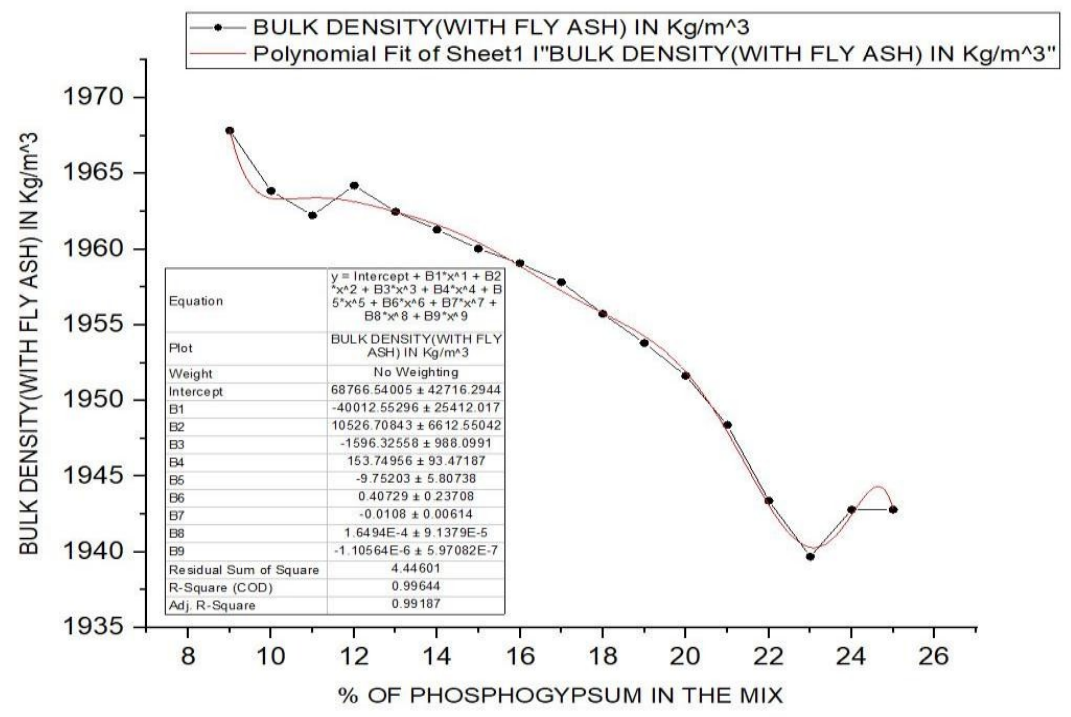

Fig 13: Variation of Bulk density with percentage of Phosphogypsum for Bricks with Fly Ash

From Fig 13 and table 2, it is inferred that, in case of oven dried sample with the use of fly-ash, the increase in percentage of Phospho-gypsum from $9 \%$ to $25 \%$ causes a decrease in bulk density from $1967.84 \mathrm{Kg} / \mathrm{m}^{3}$ to $1942.80 \mathrm{Kg} / \mathrm{m}^{3}$.However the only exception to this pattern may be seen at Phosphogypsum percentage of 23 where the bulk-density drops to 1939.69 $\mathrm{Kg} / \mathrm{m}^{3}$. The lowest and highest being bulk densities being $1939.69 \mathrm{Kg} / \mathrm{m} 3$ and $1967.84 \mathrm{Kg} / \mathrm{m} 3$ corresponding to phosphogypsum percentages of 23 and 9.00 , respectively.

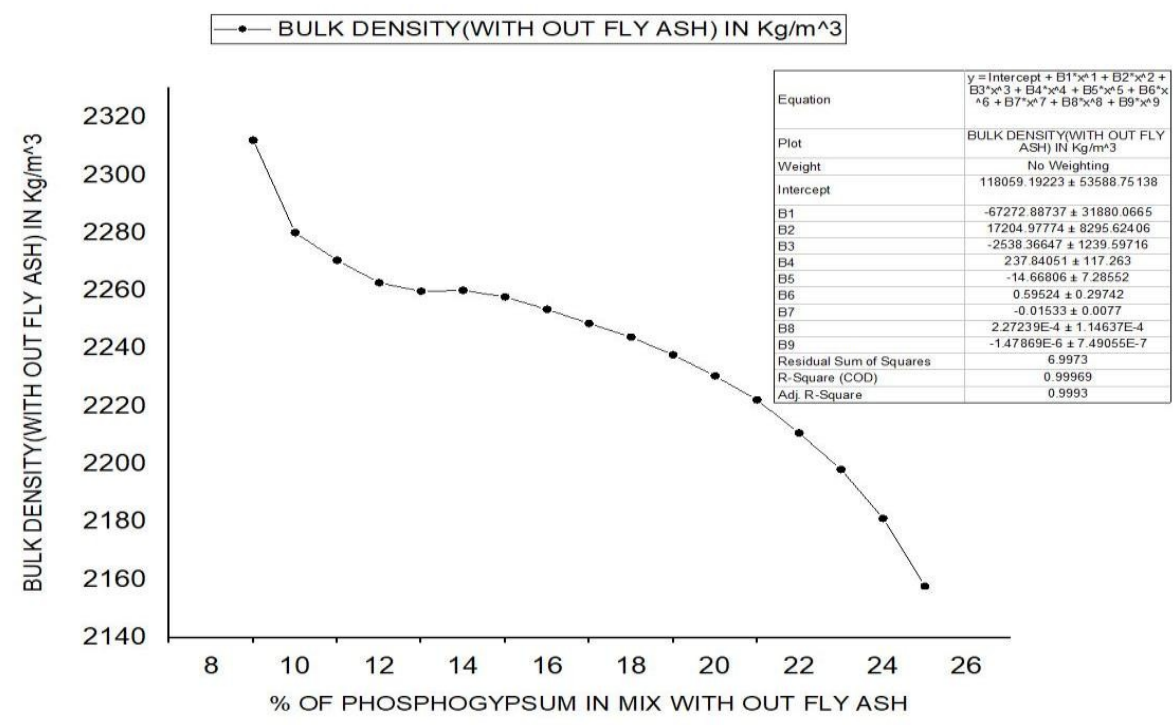

Fig 14: Variation of Bulk density with percentage of Phosphogypsum for Bricks without Fly Ash

From Fig 14 and table 2, it is inferred that, in case of oven dried sample without the use of fly-ash, the increase in percentage of
Phospho-gypsum from $9 \%$ to $25 \%$ causes a decrease in bulk density from $2312.18 \mathrm{Kg} / \mathrm{m}^{3}$ to $2157.92 \mathrm{Kg} / \mathrm{m}^{3}$. With the 
lowest and highest being $2157.92 \mathrm{Kg} / \mathrm{m} 3$ and $2312.18 \mathrm{Kg} / \mathrm{m} 3$ corresponding to phospho-gypsum percentages 25.00 and 9.00 percentages, respectively.
The results obtained for different bricks properties for different Fly-ash percentages are presented in table 3 below.

Table 3: Oven-Cured Brick: \% of Fly-Ash vs Brick Properties

\begin{tabular}{|c|c|c|c|c|c|}
\hline SL. NO. & $\begin{array}{c}\text { \% OF FLY-ASH IN } \\
\text { THE MIX }\end{array}$ & $\begin{array}{c}\text { COMPRESSIVE } \\
\text { STRENGTH } \\
\text { (WITH FLY ASH), }\end{array}$ & $\begin{array}{c}\text { \% WEIGHT GAIN } \\
\text { (ABSORBTION) } \\
\text { (WITH FLY ASH) }\end{array}$ & $\begin{array}{c}\text { DRY DENSITY } \\
\text { (WITH FLY ASH) } \\
\text { IN Kg/m^3 }\end{array}$ & $\begin{array}{c}\text { BULK DENSITY } \\
\text { (WITH FLY ASH) } \\
\text { IN Kg/m^3 }\end{array}$ \\
\hline & & & & & \\
\hline 1 & 9.00 & 19.58 & 17.15 & 1839.37 & 2154.78 \\
\hline 2 & 10.00 & 18.86 & 17.72 & 1833.06 & 2157.84 \\
\hline 3 & 11.00 & 18.62 & 17.70 & 1826.00 & 2149.26 \\
\hline 4 & 12.00 & 18.33 & 17.69 & 1818.06 & 2139.63 \\
\hline 5 & 13.00 & 18.02 & 17.68 & 1809.07 & 2128.94 \\
\hline 6 & 14.00 & 17.70 & 17.67 & 1798.79 & 2116.70 \\
\hline 7 & 15.00 & 17.37 & 17.65 & 1786.92 & 2102.24 \\
\hline 8 & 16.00 & 17.02 & 17.69 & 1773.08 & 2086.78 \\
\hline 9 & 17.00 & 16.66 & 17.71 & 1756.73 & 2067.77 \\
\hline 10 & 18.00 & 16.61 & 17.58 & 1739.02 & 2044.63 \\
\hline 11 & 19.00 & 22.87 & 17.77 & 1768.16 & 2082.33 \\
\hline 12 & 20.00 & 19.29 & 17.59 & 1735.50 & 2040.75 \\
\hline 13 & 21.00 & 22.46 & 17.79 & 1746.41 & 2057.15 \\
\hline 14 & 22.00 & 21.49 & 17.68 & 1727.74 & 2033.28 \\
\hline 15 & 23.00 & 22.05 & 17.67 & 1718.87 & 2022.62 \\
\hline 16 & 24.00 & 21.76 & 17.68 & 1701.31 & 2002.08 \\
\hline 17 & 25.00 & 20.79 & 16.79 & 1697.12 & 2001.08 \\
\hline
\end{tabular}

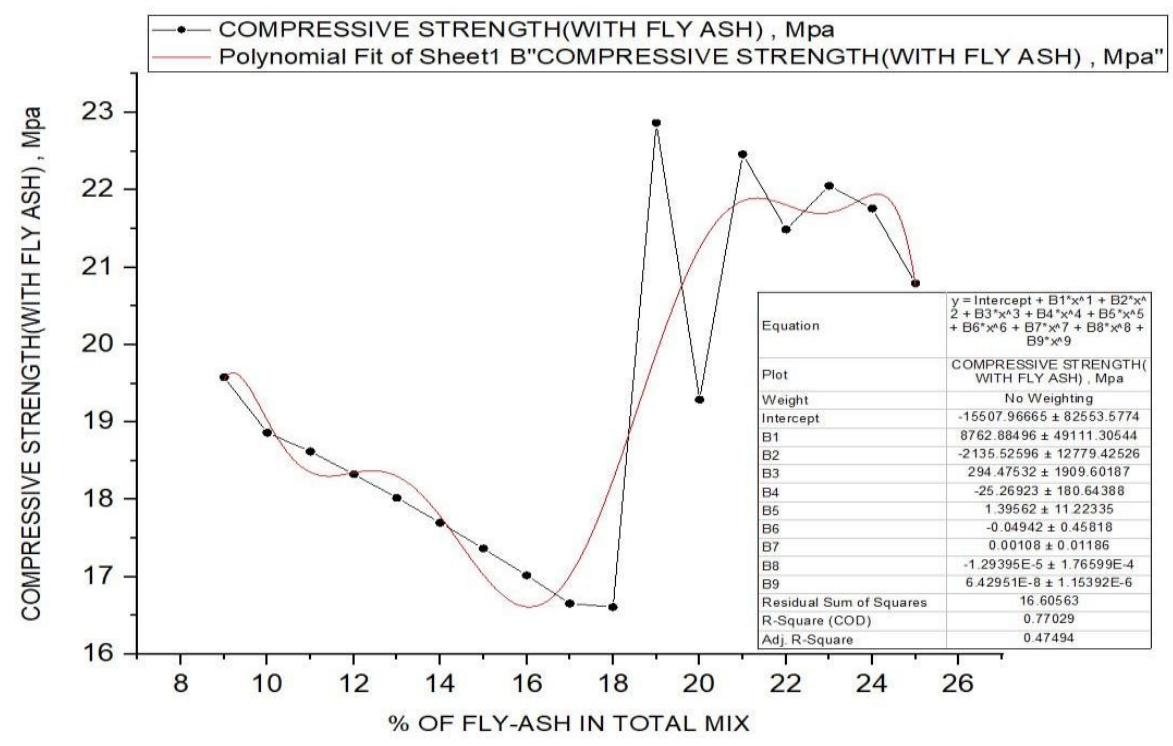

Fig 15: Variation of compressive strength with percentage of fly-ash

From Fig 15 and table 3, it is inferred that, when the percentage of Fly-ash increases from $9 \%$ to $18 \%$ the compressive strength decreases from 19.58 $\mathrm{MPa}$ to $16.61 \mathrm{MPa}$. When Fly-ash percentage increases from $19 \%$ to $25 \%$, the effect on compressive strength is random and does not follow a particular pattern and values vary between 22.87 MPa and 20.79 $\mathrm{MPa}$.
The highest and lowest values of compressive strength are 22.87 $\mathrm{MPa}$ and $18.02 \mathrm{MPa}$, corresponding to Fly-ash Percentages of 19 and 13 , respectively. 


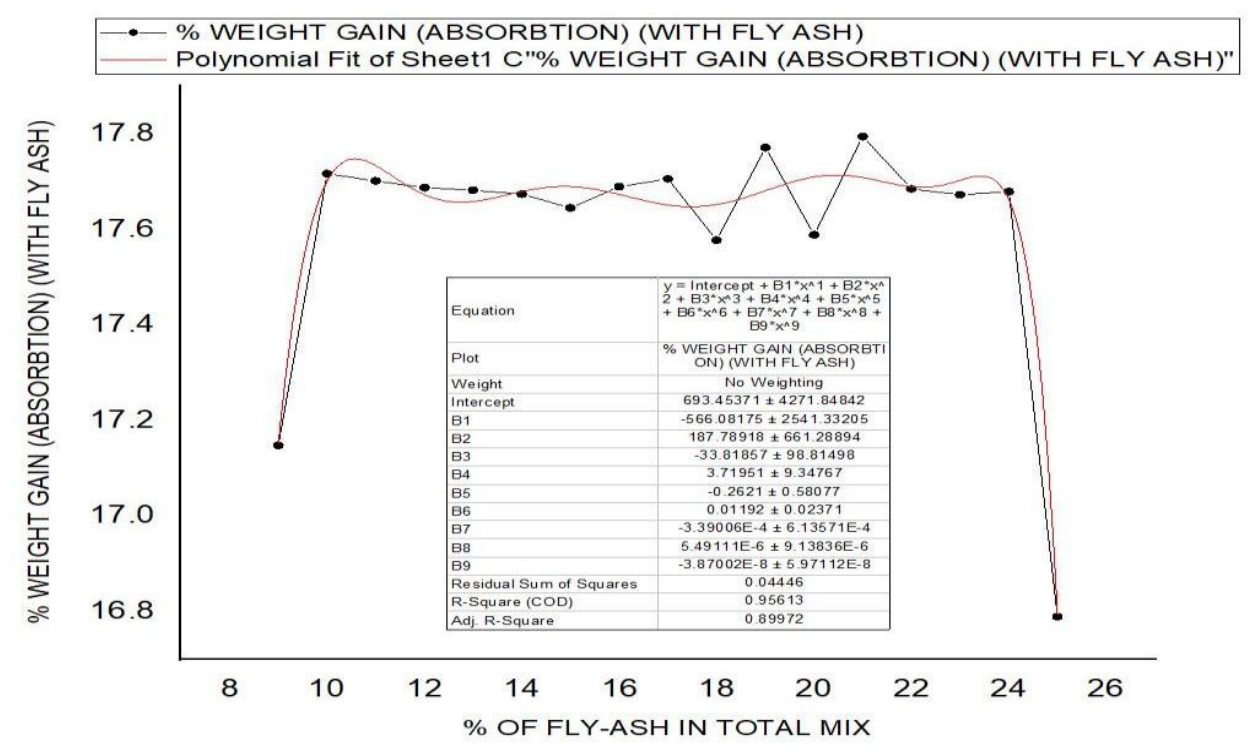

Fig 16: Variation of percentage of weight gain with percentage of fly-ash

From Fig 16 and table 3 it is inferred that; when the percentage of Fly-ash increases from $9 \%$ to $10 \%$ the water absorbtion increases from $17.15 \%$ to $17.72 \%$. When percentage of Flyash increases from $11 \%$ to $14 \%$ the water absorbtion decreases from $17.70 \%$ to $17.67 \%$. When the percentage of Fly-ash increases from $15 \%$ to $17 \%$, the water absorbtion increases from $17.65 \%$ to $17.71 \%$. For Fly-ash percentage between 18
$\%$ to $22 \%$ the water absorbtion does not follow any particular pattern and is rather random and values vary between $17.58 \%$ and $17.68 \%$. For Fly-ash percentage between $23 \%$ to $25 \%$, the water absorbtion decreases from $17.67 \%$ to $16.79 \%$. The highest and lowest values being $17.72 \%$ and $16.79 \%$ corresponding to $10 \%$ and $25 \%$ respectively.

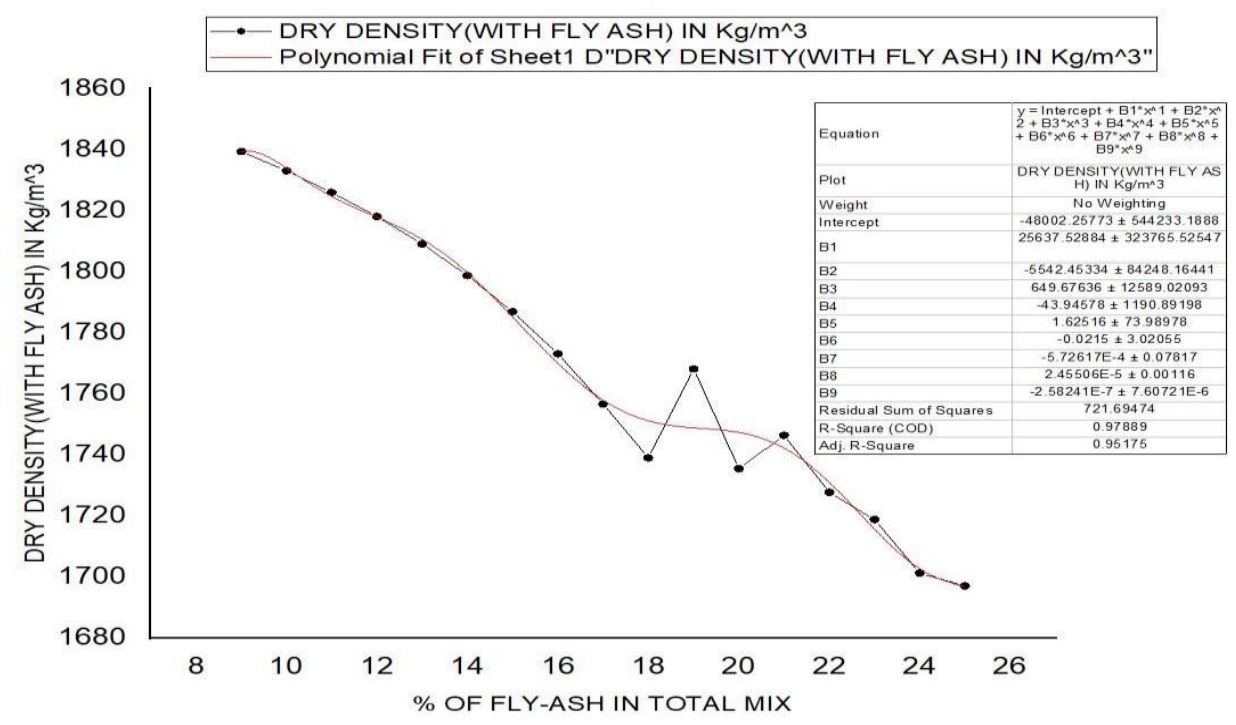

Fig 17: Variation of percentage of dry density with percentage of fly-ash

From Fig 17 and table 3 it is inferred that; when the percentage of Fly-ash increases from $9 \%$ to $18 \%$ the dry density decreases from $1839.37 \mathrm{Kg} / \mathrm{m}^{3}$ to $1739.02 \mathrm{Kg} / \mathrm{m}^{3}$. When percentage of Flyash increases from $19 \%$ to $21 \%$ the dry density follows a random and non-particular pattern and values vary between $1768.16 \mathrm{Kg} / \mathrm{m}^{3}$ and $1746.41 \mathrm{Kg} / \mathrm{m}^{3}$. When the percentage of
Fly-ash increases from $22 \%$ to $25 \%$, the dry density decreases from $1727.44 \mathrm{Kg} / \mathrm{m}^{3}$ to $1697.12 \mathrm{Kg} / \mathrm{m}^{3}$. The highest and lowest values being $1839.37 \mathrm{Kg} / \mathrm{m}^{3}$ and $1697.12 \mathrm{Kg} / \mathrm{m}^{3}$ corresponding to $9 \%$ and $25 \%$ respectively. 


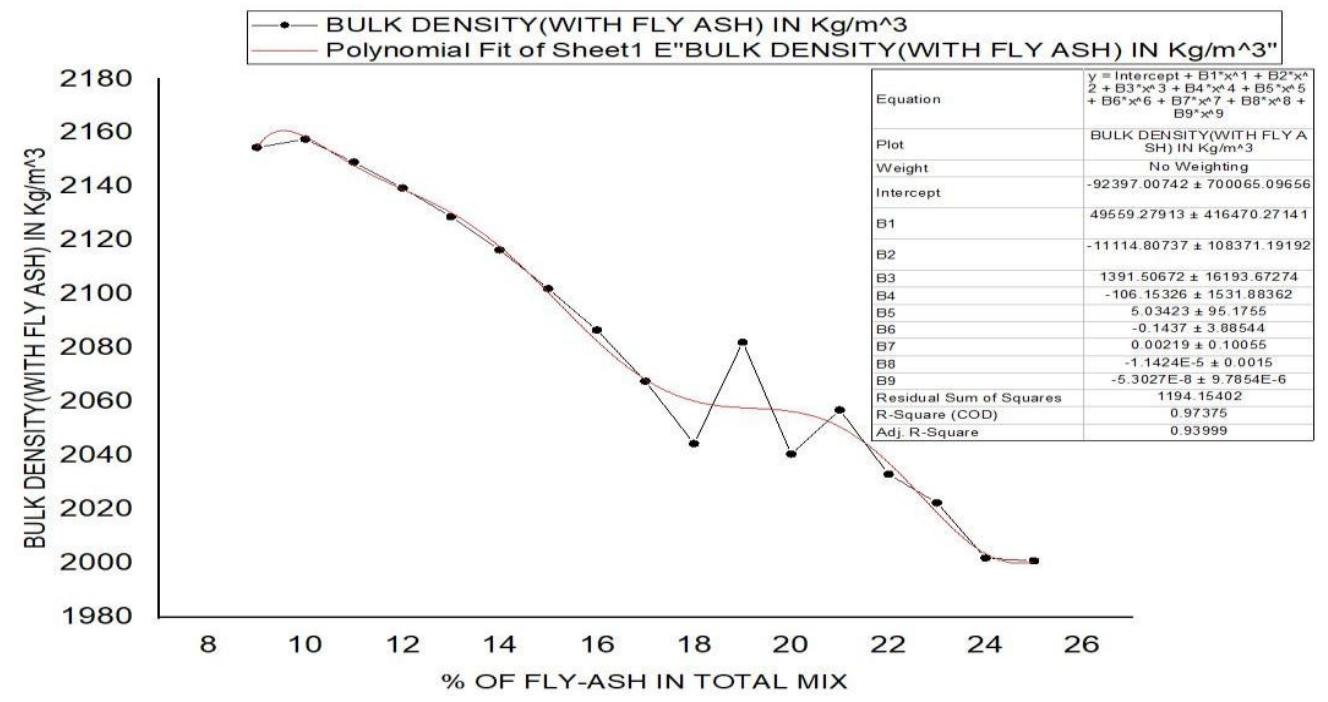

Fig 18: Variation of bulk density with percentage of fly-ash

From Fig 18 and table 3 it is inferred that; when the percentage of Fly-ash increases from $9 \%$ to $10 \%$ the bulk density increases from $2154.78 \mathrm{Kg} / \mathrm{m}^{3}$ to $2157.84 \mathrm{Kg} / \mathrm{m}^{3}$. When the percentage of Fly-ash increases from $11 \%$ to $18 \%$ the bulk density decreases from $2149.26 \mathrm{Kg} / \mathrm{m}^{3}$ to $2044.63 \mathrm{Kg} / \mathrm{m}^{3}$. When percentage of Fly-ash increases from $19 \%$ to $21 \%$ the bulk density follows a random and non-particular pattern and values vary between $2082.33 \mathrm{Kg} / \mathrm{m}^{3}$ and $2057.15 \mathrm{Kg} / \mathrm{m}^{3}$. When the percentage of Fly-ash increases from $22 \%$ to $25 \%$, the bulk density decreases from $2033.28 \mathrm{Kg} / \mathrm{m}^{3}$ to $2001.08 \mathrm{Kg} / \mathrm{m}^{3}$. The highest and lowest values being $2157.84 \mathrm{Kg} / \mathrm{m}^{3}$ and 2001.08 $\mathrm{Kg} / \mathrm{m}^{3}$ corresponding to $10 \%$ and $25 \%$ respectively.

\section{CONCLUSIONS}

It has been established through detailed experimentation that Phosphogypsum based geo-polymer concrete can be used to make bricks with compressive strengths in excess of $7.5 \mathrm{MPa}$. These bricks can be used for non-load bearing applications. Some proportions have given more than $12.5 \mathrm{MPa}$ compressive strength. So, these proportions may be used for load bearing applications as well. Even without the use of flyash required compressive strengths are attained. With the use of fly- ash the density of these bricks has reduced than compared to density of brick without the use of Fly-ash. These bricks being the almost same weight of red bricks will help reduce the overall cost of the building structure and since they have uniform finish, plastering cost and overall time can be reduced. Low porosity and high acid resistance would make the brick durable on a long-term basis. Low water absorbtion makes the use of this brick ideal in water/liquid retaining structures.

Phosphogypsum be used in combination with other organic materials like rice husk, sugarcane bagasse etc. or inorganic materials like granite powder, plastic waste or saw dust etc. and its effect studied. (like enhanced compressive strength, quick settings time etc.)

\section{REFERENCES}

[1] D u x s o n , P., Provis, J. L., Lukey, G. C., \& Van Deventer, J. S. J. (2007). The role of inorganic polymer technology in the development of "green concrete." Cement and Concrete Research, 37(12), 1590-1597.

[2] Joseph, B., \& Mathew, G. (2012). Influence of aggregate content on the behavior of fly ash based geopolymer concrete. Scientia I r a n i c a, 19(5),11881194.

[3] Olivia, M., \& Nikraz, H. (2012). Properties of fly ash geo-polymer concrete designed by Taguchi method. Materials \& Design (1980-2015), 36, 191-198.

[4] Sarker, P. K., Haque, R., \& Ramgolam, K. V. (2013). Fracture behavior of heat cured fly ash based geopolymer concrete. Materials \& Design,44, 580-586.

[5] Rangan, B. \& Wallah, Steenie \& Sumajouw, D.\& Hardjito, Djwantoro. (2006). Heat-cured, lowcalcium, fly-ash-based Geo-polymer concrete. Indian Concrete Journal. 80. 47-52.

[6] J. Davidovits (1991). Geo-polymers: Inorganic Polymeric New Materials. JOURNAL OF THERMAL ANALYSIS VOL. 37, PP. 1633-1656.

[7] Cheng, T. W., \& Chiu, J. P. (2003). Fire-resistant geopolymer produced by granulated blast furnace slag. Minerals Engineering, 16(3), 205-210.

[8] Vijaya Rangan, B. (2014). Geo-polymer concrete for environmental protection. Indian Concrete Journal. 88. 41-59.

[9] Patnaikuni, I. \& Setunge, Sujeeva \& Solikin, Mochamad \& Ling, Xiao \& Boina, Bindu. (2013). High Strength High Volume Fly Ash Concrete. 805-810. 10.3850/978-981-07-5354-2_M-62-464.

[10] Dr. Vaishali. G. Ghorpade, Dr. Sudarsana Rao, H., B.V. Ramana Prasad (2013). Deriving Mix Proportions for Different Grades of Phosphogypsum 
Based Self Compacting Concrete. International Journal of Engineering Research and Applications (IJERA) Vol 3. Issue 3. May-June 2013,467-473.

[11] Manoj Kumar Manugunta, Naveena Kanaboyana (2015). Experimental studies on strength characteristics of 12 M Geopolymer Mortar Based on Fly-ash and GGBS. International Journal of Innovative Research in Science, Engineering and Technology 4, Issue 5, May 2015.2911-2919.

[12] IS: 1707:1992 (2002) Indian Standard Code of Practice Common brunt clay building bricks-specification. $5^{\text {th }}$ Edition, Bureau of Indian Standards, New Delhi

[13] IS: 1905-1987 (2002) Indian Standard Code of Practice for Structural Use of Unreinforced Masonry. 3rd Edition, Bureau of Indian Standards, New Delhi.

[14] IS 3495: Part 1: 2019, Indian Standard Code of Practice for, Burnt Clay Building Bricks-Methods of Tests Part 1 Determination of Compressive Strength (Fourth Revision). Bureau of Indian Standards, New Delhi.

[15] IS 3495: Part 2: 2019, Indian Standard Code of Practice for, Burnt Clay Building Bricks-Methods of Tests Part 2 water absorbtion (Fourth Revision). Bureau of Indian Standards, New Delhi.

[16] IS 5454: 1976, Indian Standard Code of Practice for, Burnt Clay Building Bricks-Methods of Method for sampling clay building bricks (First edition.) Bureau of Indian Standards, New Delhi. 